\title{
Assessment of Sachet and Bottled Water Quality in Ibadan, Nigeria
}

\author{
Augustine I Airaodion ${ }^{1 *}$, Ogbonnaya Ewa ${ }^{2}$, Olaide 0 Awosanya $^{3}$, Emmanuel 0 Ogbuagu $^{4}$, Uloaku Ogbuagu ${ }^{1}$ \\ and Davidson Okereke ${ }^{2}$ \\ ${ }^{1}$ Department of Biochemistry, Federal University of Technology, Nigeria \\ ${ }^{2}$ Department of Medical Biochemistry, Gregory University, Nigeria \\ ${ }^{3}$ Department of Premedical Science, Educational Advancement Centre, Nigeria
}

${ }^{4}$ Department of Pharmacology and Therapeutics, Abia State University, Nigeria

*Corresponding author: Augustine I Airaodion, Department of Biochemistry, Federal University of Technology, Owerri, Nigeria.

Received Date: April 08, 2019

Published Date: April 26, 2019

\section{Abstract}

Background: With the recent increase in the consumption of sachet and bottled water in major cities and towns of Nigeria due to lack of portable drinking water, there is need to investigate the prevalence of possible contaminants in these water that may have toxicological effect on human when consumed.

Aim: Quality assessment of sachet and bottled water produced and/or sold in Ibadan, Nigeria was the aim of this study.

Place and duration of study: This research was carried out in Ibadan, the Oyo State capital of Nigeria between November 2018 and February 2019.

Methodology: Twenty sachet and five bottled drinking water brands; making a total of 25 brands from different manufacturers were used for this study. They were purchased randomly from local markets, shops and street vendors within Ibadan metropolis. They were clearly marked for easy identification and transported to the Quality Assurance Laboratory of Water Corporation, Eleyele, Ibadan for immediate analysis. The samples were examined physically and information on the packages were recorded. Each product was carefully opened to avoid contamination. The physical, chemical and bacteriological qualities as well as the mineral composition of all samples were analyzed using standard methods and results were compared with the recommended WHO/NIS guidelines for quality water.

Results: Physical examination indicated that all the sampled water were registered with NAFDAC but $70 \%$ of the sachet water had no manufacturing and expiry dates. The results of physical, chemical and bacteriological qualities as well as the mineral composition of sachet and bottled drinking water analyzed showed that $90 \%$ of the values were within the guideline of WHO/NIS for quality water.

Conclusion: Though, the average temperature values of both the sachet and bottled drinking water samples were significantly above the WHO/ NIS standard, it did not have any effect on their microbiological quality properties. Total coliforms, faecal coliforms and enterococci bacteria that principally characterize drinking water quality were not present in any of the water samples. Generally, the results obtained in this study indicated that sachet and bottled drinking water produced and/or sold in Ibadan metropolis were of good quality and hygienic for consumption.

Keywords: Sachet and bottled water; Quality assessment; WHO/NIS guidelines; Ibadan

\section{Introduction}

Water is one of the indispensable resources for the continued existence of all living things including man and adequate supply of fresh and clean drinking water is a basic need for all human beings [1]. In nature, all water contain impurities; as water flows in streams, accumulates in lakes and filters through layers of soil and rock in the ground, it dissolves or absorbs substances it come in contact with, which may be harmful or harmless [2].One of the major and critical problems in most developing countries today is the provision of an adequate and safe drinking water to its populace [3]. Drinking water that is safe and aesthetically acceptable is a matter of high priority to Standard Organization of Nigeria (SON), 
National Agency for Foods and Drugs Administration and Control (NAFDAC) and other regulatory agencies in Nigeria and is expected to meet the Nigerian Industrial Standard (NIS). Furthermore, drinking water that is fit for human consumption is expected to meet the World Health Organization (WHO) standard and be free from physical and chemical substances as well as microorganisms in an amount that can be hazardous to health [4]. It is a known fact that no single method of purification can eliminate $100 \%$ contaminants from drinking water. However, water can be and should be made safe for consumption within acceptable limits [4].

Sachet and bottled water are any commercially treated water, manufactured, packaged and distributed for sale in sealed food grade containers and is intended for human consumption. The difference between the two types of water is the material used to package them. It is also believing that bottled water is purer than sachet water. In Nigeria and other countries, sachet water is often referred to as 'pure water.' The production of sachet water in Nigeria started in the late $90 \mathrm{~s}$ and today the advancement in scientific technology has made sachet water production one of the fastest growing industries in the country. Water consumers are frequently unaware of the potential health risks associated with exposure to water borne contaminants which have often led to diseases like diarrhea, cholera, dysentery, typhoid fever, legionnaire's disease and parasitic diseases [5]. The continuous increase in the sale and indiscriminate consumption of packaged drinking water in Nigeria is of public health significance, as the prevalence of water related diseases in developing countries like Nigeria is determined by the quality of their drinking water [6].

The safety of drinking water in poor and deprived communities has in the last decade been in jeopardy as a result of the introduction of refuse and sewage into sources of water supply. The intake of unwholesome water could have devastating effects on health as unsafe drinking water is a key determinant of many microbial diseases with serious complications in immune-competent and immune-compromised individuals. The introduction of sachet water was aimed at providing safe, hygienic and affordable instant drinking water to the public and to curb the magnitude of water related infections in the country [6].

Earlier investigations conducted in Bauchi, Kano, Owerri, Lagos and Zaria (some major cities in Nigeria) on the safety of drinking water have shown that bottled water has good microbiological quality while the quality of some sachet water was noted to be doubtful. This observation was based on studies carried out on water samples to ascertain the presence of heterotrophic bacteria, indicators of faecal contamination (total coliforms, faecal coliforms and enterococci) and for lead, manganese and iron [7]. Lack of information on pathogenic or parasitic organisms associated with drinking water creates some uncertainties in our understanding of the overall quality of drinking water in our markets. Some sachet waters have been reported to contain bacteria such as Bacillus sp., Pseudomonas sp., Klebsiella sp., Streptococcus sp., and oocysts of Cryptosporidia $s p$. Apart from environmental contaminants, improper storage and handling by vendors also poses a serious threat to the health of the ignorant consumers [5].

Pure water is known to be colorless, odourless and tasteless with high boiling and melting points as well as high heat of vapourization. Pure water can be slightly ionized reversibly to yield hydrogen and hydroxyl ions. Therefore, water is not just a solvent in which the chemical reactions of the living cell occur [8]. It is often considered in direct participation in those reactions [9]. Quality of drinking water is evaluated based on its chemical components. This is done by assessing the $\mathrm{pH}$, hardness, total alkalinity, dissolved oxygen, carbon dioxide, heavy metals and organic constituents [4].

Consumption of sachet water in Nigeria is on the increase irrespective of whether they have NAFDAC Certification or not. However, despite the strong effort by NAFDAC in the regulation and quality assessment of sachet water and other foods and drugs in Nigeria, most manufacturers have not complied with the agency's regulation $[10,11]$. There are a growing number of reported public illnesses such as typhoid, diarrhea and other water borne diseases arising from consumption of sachet water [2]. Sachet water serves as a major source of potable drinking water in Ibadan and it environ as well as most cities in Nigeria.

Several studies have been carried out on water quality of varying degrees and coverage. Some were carried out on the chemical quality of the water, some on the microbiological quality, some on the physical quality and some on the physiochemical quality of the water. For instance [12], in their study of sachet water packaged within Kano metropolis, analyzed the physicochemical characteristics (color, taste, odour, alkalinity, total hardness, $\mathrm{pH}$, chloride, sodium, potassium, calcium, lead, zinc, chromium, copper, cobalt, nickel and manganese) using standard methods. All samples were tasteless, colorless and odourless. The $\mathrm{pH}$, alkalinity and total hardness were within WHO [13] permissible limit. The concentration of sodium, potassium and calcium was found to be within the acceptable limit and the chloride of most of the samples is above the WHO [13] acceptable limit. The concentrations of all the heavy metals (lead, chromium, and nickel) analyzed in that study were found to be above the WHO [13] permissible limit, while concentrations of copper and zinc were below the WHO [13], permissible limit. Manganese concentration was found to fall within WHO permissible limit in $70 \%$ of the total samples, while $17 \%$ of the samples have concentrations above the WHO standard and four of the samples have concentration below the WHO recommendation. [14] examined the microbiological quality of sachet drinking water and bottled water sold on the streets of Kumasi, Ghana and concluded that bottle water in the Ghanaian market is of good microbiological quality. [15] studied the relationship between ground (well) water quality and refuse dumpsites in Zaria. [16] studied the quality of sachet and bottle water in Boltanga municipal of Ghana.

Danso-Boatengand Frimpong [17] studied the quality analysis of plastic sachet and bottled water brands produced or sold in Kumasi, Ghana. [18] studied the physiochemical quality of sachet water 
consumed in Kano metropolis. [19] studied the microbiological analysis of packaged drinking water sold in Chennai, India. [20] studied the assessment of sachet water quality in Zaria area of Kaduna State, Nigeria. [21] studied the qualitative assessment of sachet and bottled water marketed in Bauchi metropolis, Nigeria. [22] studied the drinking water quality assessment and its effects on residents' health in Wondo genet campus, Ethiopia. The aim of this study is to provide more information on the quality of sachet and bottled water produced and/or sold in Ibadan, Western Nigeria, by collecting samples randomly from local markets, shops and street vendors within the Ibadan metropolis, analyzing them in the laboratory and assessing their quality in comparison with the World Health Organization (WHO) and Nigerian Industrial Standard (NIS) standard for quality water.

\section{Materials and Methods}

Study area

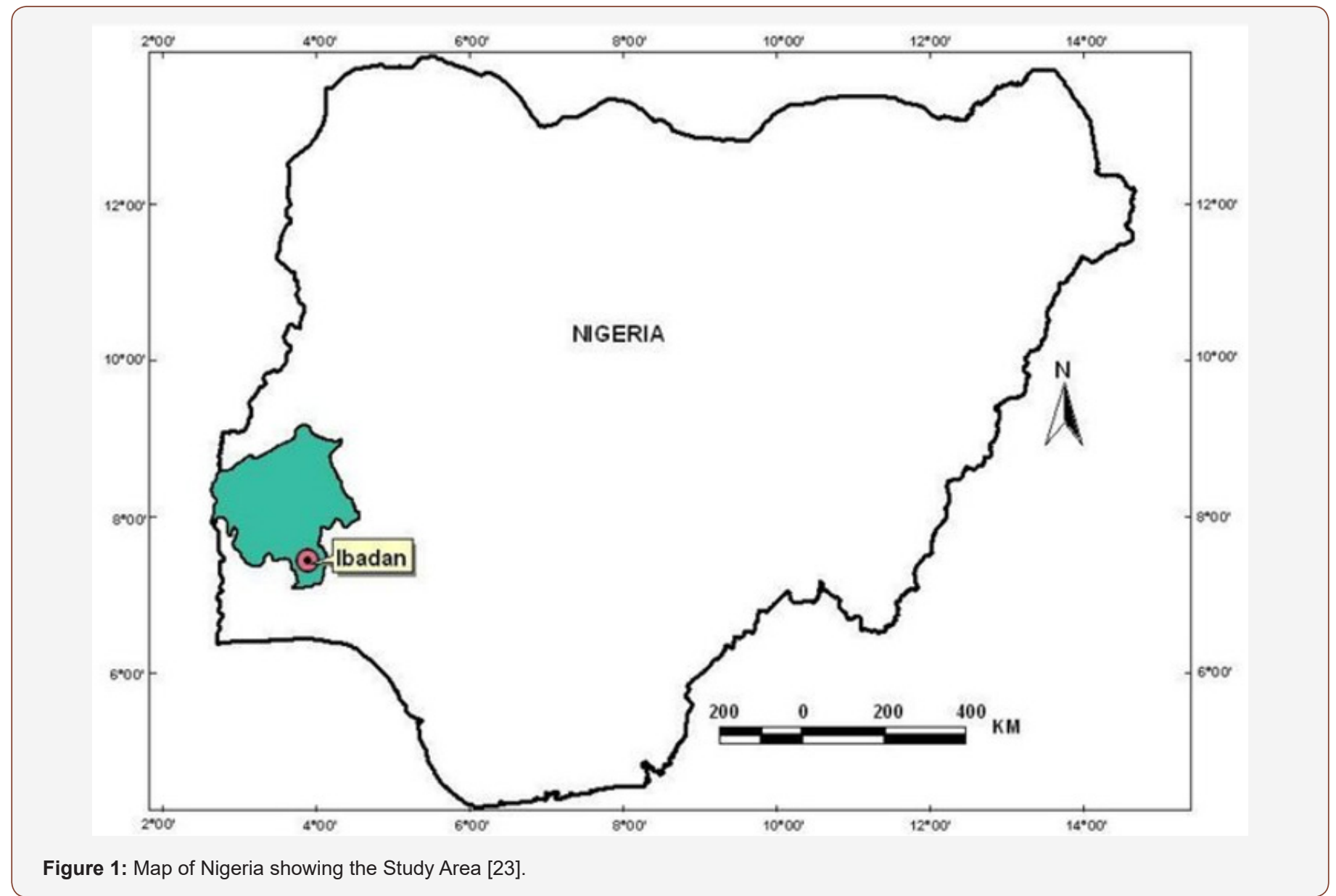

Ibadan is the capital and most populous city of Oyo State, Nigeria. With a population of over 3 million, it is the third most populous city in Nigeria after Lagos and Kano; it is the country's largest city by geographical area. At the time of Nigeria's independence in 1960, Ibadan was the largest and most populous city in the country, and the second most populous in Africa after Cairo [23]. Ibadan is in south-western Nigeria, $128 \mathrm{~km}$ inland northeast of Lagos and 530km southwest of Abuja, the Federal Capital, and is a prominent transit point between the coastal region and the areas in the hinterland of the country. Ibadan had been the centre of administration of the old Western Region since the days of the British colonial rule, and parts of the city's ancient protective walls still stand to this day. The principal inhabitants of the city are the Yorubas, as well as various communities from other parts of the country [23]. It is an urban centre where both sachet and bottled water are produced and sold (Figure 1).

\section{Sampling of sachet and bottled water}

Twenty (20) sachet and 5 bottled drinking water brands; making a total of 25 brands from different manufacturers were used for this study. These are the most popular and consumed brands in Ibadan. Triplicate batches of each brand were purchased randomly from local markets, shops and street vendors within Ibadan Metropolis. The samples were clearly marked for easy identification and transported to the Quality Assurance Laboratory of Water Corporation, Eleyele, Ibadan for immediate analysis. The samples were examined physically and information on the packages were recorded. Each product was carefully opened to avoid contamination. For bottled water, the cap of each bottle was carefully removed to avoid tou ching the opening. In the case of sachet water, an edge of the package was cut with a sterilized scissors and carefully placed in a sterilized beaker. The physical, chemical and bacteriological parameters as well as mineral composition were 
determined by taking water directly from the original package (sachet or bottle) and tested. Twenty-five (25) bottled samples and one hundred (100) sachet water samples were analyzed, with five (5) samples from each brand for a total 125 samples.

\section{Physical examination of sachet and bottled water}

Physical examination of labeling information was carried out according to the method described by [24].

\section{Determination of physical qualities}

Temperature was measured using Standard Method 2550 B: Laboratory and Field Methods, using a multipurpose $\mathrm{pH}$ meter (HANNA pH 209, USA) adjusted for temperature in Degrees Celsius $\left({ }^{\circ} \mathrm{C}\right)$, as detailed in Standard Methods for the Examination of Water and Wastewater [25]. Color was determined using Standard Method 2120 C: Spectrophotometric Method, with an ultra violet (U.V.) spectrophotometer (HACH LANGE DR 5000, USA.) expressed in hazen units (HU), according to Standard Methods for the Examination of Water and Wastewater [25]. The turbidity was measured using Standard Method 2130 B: Nephelometric Method, by turbidimeter (HACH 2100P, USA) in Nephelometric Turbidity Units (NTU), as explained in Standard Methods for the Examination of Water and Wastewater [25]. Conductivity was determined using Standard Method 2510 B: Laboratory Method, via a conductivity meter (JENWAY 4510, U.K) in micro-Siemens per centimeter $(\mu \mathrm{s} / \mathrm{cm})$, as detailed in Standard Methods for the Examination of Water and Wastewater [25]. Total dissolved solids (TDS) and total suspended solids (TSS) were determined using Standard Methods 2540 B: Total Dissolved Solids Dried at $103-105{ }^{\circ} \mathrm{C}$ and 2540 D: Total Suspended Solids Dried at $103-105^{\circ} \mathrm{C}$, respectively. The units were expressed in $\mathrm{mg} / \mathrm{L}$ according to Standard Methods for the Examination of Water and Wastewater [25].

\section{Determination of chemical qualities}

Alkalinity was determined using Standard Method 2320 B: Titration Method in mg/L, as explained in Standard Methods for the Examination of Water and Wastewater [25]. Total hardness and calcium hardness were determined using Standard Method $2340 \mathrm{C}$ : EDTA Titrimetric Method and Standard Method 3500-Ca-B: EDTA Titrimetric Method, respectively, as detailed in Standard Methods for the Examination of Water and Wastewater [25]; expressed in $\mathrm{mg} / \mathrm{L}$. Chloride was analysed using Standard Method 4500-Cl-B: Argentometric Method in mg/L, and $\mathrm{pH}$ measured using Standard Method 4500- $\mathrm{H}^{+}$B: Electrometric Method, by a multipurpose $\mathrm{pH}$ meter (HANNA pH 209, USA), according to Standard Methods for the Examination of Water and Wastewater [25].

\section{Determination of minerals and heavy metals in sachet and bottled water}

The following minerals and heavy metals; Calcium (Ca), Cadmium (Cd), Chloride (Cl), Chromium (Cr), Copper (Cu), Iron $(\mathrm{Fe})$, Potassium $(\mathrm{K})$, Manganese $(\mathrm{Mn})$, Sodium $(\mathrm{Na})$, Lead $(\mathrm{Pb})$ and Zinc (Zn) were determined for each water sample using Atomic absorption spectrophotometry (Buck Scientific, VPG 210) procedure as reported [26,27].

\section{Determination of bacteriological qualities}

Total coliform and faecal coliform organism numbers were determined using Standard Method 9221 B: Standard Total Coliform Fermentation Technique. Heterotrophic bacteria were enumerated using Standard Method 9215 C: Spread Plate Method, according to Standard Methods for the Examination of Water and Wastewater [25]. Gallenkamp, Economic Incubator Size 2, England was used. The number of colonies forming organisms was counted manually, and again, bottles inspected for the formation of acids and gases in vial.

\section{Statistical analysis}

Data were subjected to analysis using Graph Pad Prism, version 6.0. Results were presented as mean \pm standard deviations. One-way Analysis of Variance (ANOVA) followed by Turkey's test was used for comparison of the mean. Differences between the experimental mean and WHO/NIS standard values were significant at $\mathrm{p}<0.05$.

\section{Results and Discussion}

According to World Health Organization (WHO), diarrheal diseases account for an estimated $4.1 \%$ of the total daily global burden and are responsible for the deaths of 1.8 million people every year. It was estimated that $88 \%$ of that burden is attributable to unsafe water supply, sanitation and hygiene [28]. The National Agency for Food, Drug Administration and Control (NAFDAC), the agency responsible for regulating drugs, foods and chemicals in Nigeria requires that all the labeling of food and drugs must be informative and accurate. This information required on labeling include manufacturer's name, contact information, batch number, nutritional information, manufacturing date, expiration date (Best before date) and NAFDAC registration number [29,30]. The result of the physical examination of the sachet and bottled water investigated in this study is presented in (Table 1).

Table 1: Physical Examination of Sachet and Bottled Water Brands produced and/or sold in Ibadan, Nigeria.

\begin{tabular}{|c|c|c|c|c|c|c|c|}
\hline Water Samples & Product Name & $\begin{array}{c}\text { Manufacturer } \\
\text { Address }\end{array}$ & Batch Number & $\begin{array}{c}\text { Manufacturing } \\
\text { Date }\end{array}$ & Expiry Date & $\begin{array}{l}\text { NAFDAC } \\
\text { Number }\end{array}$ & $\begin{array}{c}\text { Mineral } \\
\text { Composition }\end{array}$ \\
\hline WHO/NIS & + & + & + & + & + & + & + \\
\hline \multicolumn{8}{|c|}{ Sachet Water } \\
\hline $\mathrm{A}$ & + & + & - & - & - & + & - \\
\hline B & + & + & - & - & - & + & - \\
\hline $\mathrm{C}$ & + & + & - & - & - & + & - \\
\hline $\mathrm{D}$ & + & + & - & + & + & + & - \\
\hline
\end{tabular}




\begin{tabular}{|c|c|c|c|c|c|c|c|}
\hline E & + & + & - & - & - & + & - \\
\hline $\mathrm{F}$ & + & + & - & - & - & + & - \\
\hline G & + & + & - & - & - & + & - \\
\hline $\mathrm{H}$ & + & + & - & + & + & + & - \\
\hline I & + & + & - & + & + & + & - \\
\hline $\mathrm{J}$ & + & + & - & - & - & + & - \\
\hline $\mathrm{K}$ & + & + & - & - & - & + & - \\
\hline $\mathrm{L}$ & + & + & - & + & + & + & - \\
\hline M & + & + & - & - & - & + & - \\
\hline $\mathrm{N}$ & + & + & - & - & - & + & - \\
\hline 0 & + & + & - & - & - & + & - \\
\hline $\mathrm{P}$ & + & + & - & + & + & + & - \\
\hline Q & + & + & - & - & - & + & - \\
\hline $\mathrm{R}$ & + & + & - & - & - & + & - \\
\hline$S$ & + & + & - & + & + & + & - \\
\hline $\mathrm{T}$ & + & + & - & - & - & + & - \\
\hline \multicolumn{8}{|c|}{ Bottled Water } \\
\hline $\mathrm{U}$ & + & + & + & + & + & + & - \\
\hline $\mathrm{V}$ & + & + & + & + & + & + & - \\
\hline $\mathrm{W}$ & + & + & + & + & + & + & - \\
\hline$X$ & + & + & + & + & + & + & - \\
\hline $\mathrm{Y}$ & + & + & + & + & + & + & - \\
\hline
\end{tabular}

$(+)$ indicates present while (-) indicates absent

It was observed that all the bottled water samples exhibit $100 \%$ compliance as regard the product names, manufacturers' addresses, manufacturing and expiry dates, batch number and NAFDAC registration number as this information were clearly shown on their labeling. However, none of the bottled water brand analyzed indicates the mineral compositions of the water. It was also observed that all the sachet water studied had $100 \%$ compliance in term of the product names, manufacturing addresses, and NAFDAC number. However, $85 \%$ of them had 'L' with their NAFDAC number, which implies that they might still be under listing. Only 6 out of the 20-sachet water analyzed representing 30\% had manufacturing and expiry date. This information is very essential, as they tell the consumer whether the water sample is still within its shelf life or not. Furthermore, all the sachet water studied was observed to be without batch number and mineral composition on their labeling. Batch number is essential for any product especially when there is need to recall a product from the market in the event of discovery of any abnormality with the product [21]. The act of noncompliance by the water production factories as rightly observed in this present study is a source of great concern, as the packaged water sold to the entire populace in Ibadan metropolis are likely to pose health risk when consumed.

It has been reported that substantial number of sachet water manufacturers that resist compliance to best practices laid down by the authorities do not have the license to operate [31,32]. It is however very worrisome that this is not the case with this present study as all the water manufacturers were duly certified to operate as evident in the NAFDAC registration number provided. The question here is, 'how did they get registered by NAFDAC without compliance to their guidelines?' It might be that they produced the samples given to NAFDAC to meet their guidelines before registration or they forged the NAFDAC registration number in their labels. This should be a source of great concern to NAFDAC and other regulatory agencies in Nigeria.

The results of physical, chemical and bacteriological qualities as well as the mineral composition of sachet and bottled drinking water analyzed were compared with the recommended WHO/NIS guidelines $[33,34]$ for quality water. Table 2 showed the physical qualities (temperature, color, conductivity, total suspended solids, turbidity and total dissolved solids) for the sachet and bottled water brands investigated. The standard temperature of drinking water according to WHO/NIS is $25^{\circ} \mathrm{C}$. Temperature is a measure of the average thermal energy of a substance [21]. The sachet water analyzed has 27.40 and $30.70{ }^{\circ} \mathrm{C}$ as the lowest and highest temperature respectively. The average temperature of the twentysachet water analyzed is $28.83{ }^{\circ} \mathrm{C}$ which is significantly higher than the WHO/NIS standard value for quality water. Similarly, the temperature of the bottled water analyzed ranged from 28.30 to $30.40{ }^{\circ} \mathrm{C}$ with an average of $29.58^{\circ} \mathrm{C}$. This was also significantly higher than the WHO/NIS standard value for quality water at $\mathrm{P}<0.05$.

This could be due to high temperature of 27 to $34^{\circ} \mathrm{C}$ in Ibadan during the period of this study. However, these temperatures for both sachet and bottled drinking water fell within the optimal growth temperature $\left(20-45^{\circ} \mathrm{C}\right)$ for mesophilic bacteria [35]. The 
microbiological characteristics of drinking water are related to temperature through its effects on water-treatment processes and its effects on both growth and survival of microorganisms [28]. This result is like that of Danso-Boateng and Frimpong [17] who reported $28.94{ }^{\circ} \mathrm{C}$ and $28.81{ }^{\circ} \mathrm{C}$ respectively for average temperatures of plastic sachet and bottled water brands produced and/or sold in Kumasi, Ghana. According to [36], temperatures within this range are favourable for maximum growth of mesophyll bacteria including human diseases causing agents. This phenomenon has the tendency to promote the development of undesirable taste and odour in water with time [36]. However, a report by State Water Quality Control Board in Canada indicated that the survival time in water of the cysts and ova of parasitic worms such as Schistosoma ova is shortened by higher temperatures between 29 to $32^{\circ} \mathrm{C}$ [37].
The result of this study indicated that no color was present in both sachet and bottled water investigated (Table 2). This means that all the water brands were free from dissolved humic acids [17]. The conductivity values obtained for both sachet and bottled water investigated were within the range of WHO/NIS standard conductivity $(0-1000 \mu \mathrm{s} / \mathrm{cm})$ for quality water. Conductivity is a measure of water's capability to pass electrical flow. This ability is directly related to the concentration of ions in the water [38]. These conductive ions come from dissolved salts and inorganic materials such as alkalis, chlorides, sulfides and carbonate compounds [39]. Compounds that dissolve into ions are also known as electrolytes [40]. The more ions that are present, the higher the conductivity of water. Likewise, the fewer ions that are in the water, the less conductive it is.

Table 2: Physical Qualities of Sachet and Bottled Water Brands produced and/or sold in Ibadan, Nigeria.

\begin{tabular}{|c|c|c|c|c|c|c|}
\hline Water Samples & Temperature (oC) & Colour (HU) & $\begin{array}{l}\text { Conductivity ( } \mu \mathrm{s} / \\
\mathrm{cm})\end{array}$ & TSS (mg/L) & Turbidity (NTU) & TDS $(\mathrm{mg} / \mathrm{L})$ \\
\hline WHO/NIS & 25 & $0-15$ & $0-1000$ & - & $0-5$ & 1000 \\
\hline \multicolumn{7}{|c|}{ Sachet Water } \\
\hline A & $28.1 \pm 3.44$ & 0.00 & $94.3 \pm 4.27$ & 0.00 & $0.24 \pm 0.01$ & $23.13 \pm 0.93$ \\
\hline B & $27.9 \pm 4.93$ & 0.00 & $55.8 \pm 3.92$ & 0.00 & $0.2 \pm 0.01$ & $72.2 \pm 3.23$ \\
\hline $\mathrm{C}$ & $28.7 \pm 4.14$ & 0.00 & $46.6 \pm 3.29$ & 0.00 & $0.36 \pm 0.04$ & $47.21 \pm 4.93$ \\
\hline $\mathrm{D}$ & $27.8 \pm 4.03$ & 0.00 & $77.6 \pm 9.02$ & 0.00 & $0.24 \pm 0.03$ & $58.19 \pm 6.34$ \\
\hline $\mathrm{E}$ & $30.2 \pm 4.03$ & 0.00 & $114.6 \pm 14.21$ & 0.00 & $0.14 \pm 0.00$ & $52.18 \pm 2.74$ \\
\hline $\mathrm{F}$ & $29.3 \pm 4.24$ & 0.00 & $51.5 \pm 5.32$ & 0.00 & $0.21 \pm 0.01$ & $15.35 \pm 0.87$ \\
\hline G & $28.6 \pm 4.03$ & 0.00 & $52.9 \pm 3.49$ & 0.00 & $0.29 \pm 0.03$ & $12.6 \pm 1.23$ \\
\hline $\mathrm{H}$ & $28.4 \pm 3.61$ & 0.00 & $67.7 \pm 4.91$ & 0.00 & $0.25 \pm 0.02$ & $62.83 \pm 6.12$ \\
\hline I & $29.9 \pm 4.14$ & 0.00 & $75.5 \pm 8.91$ & 0.00 & $0.22 \pm 0.02$ & $54.54 \pm 4.34$ \\
\hline $\mathrm{J}$ & $29.8 \pm 4.03$ & 0.00 & $86.7 \pm 2.88$ & 0.00 & $0.37 \pm 0.02$ & $42.21 \pm 2.84$ \\
\hline K & $28.7 \pm 3.92$ & 0.00 & $22.8 \pm 2.01$ & 0.00 & $0.18 \pm 0.01$ & $56.12 \pm 6.24$ \\
\hline $\mathrm{L}$ & $27.9 \pm 4.14$ & 0.00 & $57 \pm 6.39$ & 0.00 & $0.26 \pm 0.01$ & $29.72 \pm 3.92$ \\
\hline M & $28.9 \pm 4.14$ & 0.00 & $94.1 \pm 4.32$ & 0.00 & $0.97 \pm 0.03$ & $18.12 \pm 1.21$ \\
\hline $\mathrm{N}$ & $28.8 \pm 4.03$ & 0.00 & $136.9 \pm 10.22$ & 0.00 & $0.27 \pm 0.04$ & $22.1 \pm 1.82$ \\
\hline 0 & $27.4 \pm 3.92$ & 0.00 & $36.9 \pm 4.22$ & 0.00 & $0.25 \pm 0.03$ & $58.63 \pm 3.89$ \\
\hline $\mathrm{P}$ & $29.1 \pm 3.92$ & 0.00 & $72.1 \pm 4.08$ & 0.00 & $0.73 \pm 0.05$ & $42.15 \pm 3.18$ \\
\hline Q & $30.7 \pm 3.92$ & 0.00 & $96.9 \pm 5.39$ & 0.00 & $0.45 \pm 0.02$ & $67.82 \pm 5.22$ \\
\hline $\mathrm{R}$ & $28.6 \pm 3.92$ & 0.00 & $68.2 \pm 3.29$ & 0.00 & $0.22 \pm 0.03$ & $78.36 \pm 8.09$ \\
\hline S & $28.5 \pm 3.92$ & 0.00 & $90.9 \pm 7.21$ & 0.00 & $0.23 \pm 0.04$ & $33.11 \pm 2.54$ \\
\hline $\mathrm{T}$ & $29.2 \pm 3.92$ & 0.00 & $49.6 \pm 2.71$ & 0.00 & $0.49 \pm 0.02$ & $58.13 \pm 3.42$ \\
\hline \multicolumn{7}{|c|}{ Bottled Water } \\
\hline $\mathrm{U}$ & $30.3 \pm 4.02$ & 0.00 & $193.27 \pm 11.21$ & 0.00 & $0.2 \pm 0.00$ & $80.55 \pm 7.34$ \\
\hline $\mathrm{V}$ & $29.1 \pm 2.02$ & 0.00 & $83.5 \pm 8.13$ & 0.00 & $0.11 \pm 0.01$ & $47.2 \pm 4.92$ \\
\hline $\mathrm{W}$ & $28.3 \pm 3.32$ & 0.00 & $99.3 \pm 6.89$ & 0.00 & $0.15 \pm 0.01$ & $61.9 \pm 3.28$ \\
\hline $\mathrm{X}$ & $29.8 \pm 3.93$ & 0.00 & $117.67 \pm 14.28$ & 0.00 & $0.14 \pm 0.02$ & $39.28 \pm 3.91$ \\
\hline $\mathrm{Y}$ & $30.4 \pm 3.12$ & 0.00 & $45.93 \pm 5.27$ & 0.00 & $0.16 \pm 0.01$ & $13.61 \pm 1.23$ \\
\hline
\end{tabular}

Results are presented as mean \pm standard deviation where $n=5$. Data were statistically compared with WHO/NIS standard at $p<0.05$. - means no standard value provided for the parameter. TSS $=$ Total Suspended Solids and TDS $=$ Total Dissolved Solids.

Distilled or deionized water can act as an insulator due to its very low (if not negligible) conductivity value [41]. Sea water, on the other hand, has a very high conductivity. Ions conduct electricity due to their positive and negative charges [38]. When electrolytes dissolve in water, they split into positively charged (cation) and negatively charged (anion) particles. As the dissolved substances split in water, the concentrations of each positive and negative charge remain equal. This means that even though the conductivity of water increases with added ions, it remains electrically neutral [41]. The average conductivity of the bottled water analyzed is 
higher than that of the sachet water. This might be that the sachet waters analyzed contain fewer amounts of dissolved ions or salts than the bottled water brands.

Both sachet and bottled water analyzed in this study showed that no suspended solids were present in them to be detected. The turbidity of both sachet and bottled water were within the range given by WHO/NIS (0-5 NTU). This could account for the reason why total suspended solids (TSS) were not detectable in all the brands of sachet and bottled water analyzed, which is good for consumption. However, the sachet water samples were more turbid when compared with the bottled water analyzed. This might be attributed to the fact that, the bottled water passes through series of filters, or efficient filter medium during production to remove suspended clay particles, trace elements and suspended solids compared to the sachet water [17].

Some solids were found to have dissolved in both sachet and bottled waters investigated but they were far below the permissible level of total dissolved solids (TDS) value $(1000 \mathrm{mg} / \mathrm{L})$ of WHO/ NIS. TDS combine the sum of all ion particles that are smaller than 2 microns $(0.0002 \mathrm{~cm})$ [42]. This includes all the disassociated electrolytes that make up salinity concentrations, as well as other compounds such as dissolved organic matter. In "clean" water, TDS is approximately equal to salinity [43]. In wastewater or polluted areas, TDS can include organic solutes (such as hydrocarbons and urea) in addition to the salt ions [43]. TDS concentrations outside of a normal range can cause a cell to swell or shrink. This can negatively impact aquatic life that cannot compensate for the change in water retention. While TDS measurements are derived from conductivity, some states, regions and agencies often set a TDS maximum instead of a conductivity limit for water quality [44]. TDS can also affect water taste, and often indicates a high alkalinity or hardness [43].

The result of the chemical qualities $(\mathrm{pH}$, total hardness, and alkalinity) of sachet and bottled drinking water brands investigated in this study are presented in (Table 3 ). The $\mathrm{pH}$ of the sachet water ranged from 6.48 to 7.12 while that of the bottled water ranged from 6.62 to 7.00 . The $\mathrm{pH}$ of both the sachet and bottled water analyzed are within the standard range of $\mathrm{pH}$ (6.5-8.5) for quality water recommended by WHO/NIS. It is very important to state that the water samples with $\mathrm{pH}$ within the regulatory guideline values do not have any probability of posing health issues like as acidosis [45]. Basically, the $\mathrm{pH}$ value is a good indicator of whether water is hard or soft. The $\mathrm{pH}$ of pure water is 7. In general, water with a $\mathrm{pH}$ lower than 7 is considered acidic, and with a pH greater than 7 is considered basic. The normal range for $\mathrm{pH}$ in surface water systems is 6.5 to 8.5 , and the $\mathrm{pH}$ range for groundwater systems is between 6 and 8.5. Alkalinity is a measure of the capacity of the water to resist a change in $\mathrm{pH}$ that would tend to make the water more acidic [46].

Table 3: Chemical Qualities of Sachet and Bottled Water Brands produced and/or sold in Ibadan, Nigeria.

\begin{tabular}{|c|c|c|c|}
\hline Water Samples & pH & Total Hardness (mg/L) & Alkalinity (mg/L) \\
\hline WHO/NIS & $6.5-8.5$ & - & 500 \\
\hline \multicolumn{4}{|c|}{ Sachet Water } \\
\hline $\mathrm{A}$ & $7.02 \pm 0.12$ & $22 \pm 1.2$ & $42 \pm 7.2$ \\
\hline $\mathrm{B}$ & $6.82 \pm 0.73$ & $10 \pm 0.6$ & $62.42 \pm 7.29$ \\
\hline $\mathrm{C}$ & $6.58 \pm 0.92$ & $12 \pm 0.9$ & $74 \pm 11.29$ \\
\hline $\mathrm{D}$ & $6.96 \pm 0.24$ & $8 \pm 0.2$ & $4 \pm 0.38$ \\
\hline $\mathrm{E}$ & $7 \pm 0.52$ & $8 \pm 0.4$ & $46.62 \pm 9.47$ \\
\hline $\mathrm{F}$ & $7.12 \pm 0.68$ & $16 \pm 1.2$ & $25 \pm 5.4$ \\
\hline G & $7.03 \pm 0.09$ & $35 \pm 3.3$ & $16.25 \pm 8.34$ \\
\hline $\mathrm{H}$ & $6.73 \pm 0.11$ & $27 \pm 2.1$ & $42.28 \pm 9.45$ \\
\hline $\mathrm{I}$ & $6.48 \pm 0.31$ & $57 \pm 9.7$ & $88.83 \pm 0.3$ \\
\hline $\mathrm{J}$ & $6.92 \pm 0.39$ & $24 \pm 2.3$ & $38.34 \pm 9.32$ \\
\hline $\mathrm{K}$ & $6.56 \pm 0.52$ & $3 \pm 0.27$ & $24 \pm 6.23$ \\
\hline $\mathrm{L}$ & $6.56 \pm 0.83$ & $62 \pm 9.8$ & $48.4 \pm 12.19$ \\
\hline M & $7.12 \pm 0.73$ & $42 \pm 6.5$ & $8.48 \pm 1.23$ \\
\hline $\mathrm{N}$ & $6.82 \pm 0.27$ & $4 \pm 0.2$ & $26.68 \pm 6.35$ \\
\hline 0 & $6.57 \pm 0.18$ & $33 \pm 4.9$ & $40.34 \pm 9.28$ \\
\hline $\mathrm{P}$ & $6.61 \pm 0.2$ & $24 \pm 2.3$ & $14.14 \pm 0.82$ \\
\hline Q & $7.2 \pm 0.72$ & $16 \pm 1.2$ & $18 \pm 1.28$ \\
\hline $\mathrm{R}$ & $6.53 \pm 0.4$ & $32 \pm 5.8$ & $8.48 \pm 1.18$ \\
\hline$S$ & $6.78 \pm 0.82$ & $28 \pm 6.2$ & $64 \pm 11.29$ \\
\hline $\mathrm{T}$ & $6.66 \pm 0.37$ & $42 \pm 8$ & $76.64 \pm 10.64$ \\
\hline \multicolumn{4}{|c|}{ Bottled Water } \\
\hline $\mathrm{U}$ & $6.62 \pm 0.47$ & $4 \pm 0.2$ & $36.44 \pm 7.5$ \\
\hline
\end{tabular}




\begin{tabular}{|c|c|c|c|}
\hline V & $6.62 \pm 0.77$ & $26 \pm 4.4$ & $46.38 \pm 10.47$ \\
\hline W & $7 \pm 0.72$ & $6 \pm 0.47$ & $62.62 \pm 4.47$ \\
\hline $\mathrm{X}$ & $6.89 \pm 0.58$ & $38 \pm 7.7$ & $52.48 \pm 7.48$ \\
\hline
\end{tabular}

Results are presented as mean \pm standard deviation where $n=5$. Data were statistically compared with WHO/NIS standard at $p<0.05$. - indicates no standard value provided for the parameter.

The measurement of alkalinity and $\mathrm{pH}$ is needed to determine the corrosiveness of the water. In general, water with a $\mathrm{pH}$ less than 6.5 could be acidic, soft, and corrosive [47]. Acidic water could contain metal ions such as iron, manganese, copper, lead, and zinc. In other words, acidic water contains elevated levels of toxic metals. Acidic water can cause premature damage to metal piping and have associated aesthetic problems such as a metallic or sour taste [47]. It can also stain laundry and cause "blue-green" color staining on sinks and drains. More importantly, there is health risks associated with these toxins [46]. The primary way to treat the problem of low pH water is with the use of a neutralizer. From the results obtained in the study, the alkalinity of sachet water ranged from $4.00-88.83 \mathrm{mg} / \mathrm{L}$ while that of bottled water ranged from $8.52-62.62 \mathrm{mg} / \mathrm{L}$. Though values of alkalinity of the bottled samples were below that of sachet samples, all were below the WHO/NIS standard of $500 \mathrm{mg} / \mathrm{L}$. This present investigation was similar with studies earlier reported $[46,47]$.

The total hardness of sachet water in this study ranged from $4.00-62.00 \mathrm{mg} / \mathrm{L}$ while those of bottled water ranged from $4.00-$ $38.00 \mathrm{mg} / \mathrm{L}$. It is important to note that the hardness contents obtained for the sachet and bottled drinking water in this study does not necessarily indicate that the water poses a health risk as no standard values were given by WHO.

Table 4: Mineral Composition of Sachet and Bottled Water Brands produced and/or sold in Ibadan, Nigeria.

\begin{tabular}{|c|c|c|c|c|c|c|c|c|c|c|c|c|}
\hline $\begin{array}{c}\text { Water } \\
\text { Samples }\end{array}$ & $\begin{array}{c}\mathrm{Ca} \\
(\mathrm{mg} / \mathrm{L})\end{array}$ & $\begin{array}{c}\mathrm{Cd} \\
(\mathrm{mg} / \mathrm{L})\end{array}$ & $\mathrm{Cl}(\mathrm{mg} / \mathrm{L})$ & $\begin{array}{c}\mathrm{Cr} \\
(\mathrm{mg} / \mathrm{L})\end{array}$ & $\begin{array}{c}\mathrm{Cu} \\
(\mathrm{mg} / \mathrm{L})\end{array}$ & $\begin{array}{c}\mathrm{Fe} \\
(\mathrm{mg} / \mathrm{L})\end{array}$ & $\mathrm{K}(\mathrm{mg} / \mathrm{L})$ & $\mathrm{Mg}(\mathrm{mg} / \mathrm{L})$ & $\begin{array}{c}\mathrm{Mn} \\
(\mathrm{mg} / \mathrm{L})\end{array}$ & $\mathrm{Na}(\mathrm{mg} / \mathrm{L})$ & $\begin{array}{c}\mathrm{Pb} \\
(\mathrm{mg} / \mathrm{L})\end{array}$ & $\begin{array}{c}\mathrm{Zn} \\
(\mathrm{mg} / \mathrm{L})\end{array}$ \\
\hline $\begin{array}{c}\text { WHO/ } \\
\text { NIS }\end{array}$ & $0-0.50$ & 0.003 & $200-250$ & 0.05 & 2 & 0.3 & 0-12 & $\begin{array}{l}10.42- \\
17.05\end{array}$ & 0.5 & 200 & 0.01 & $3 \neg-5$ \\
\hline \multicolumn{13}{|c|}{ Sachet Water } \\
\hline A & $2.54 \pm 0.09$ & ND & $6.45 \pm 1.78$ & $0.01 \pm 0.00$ & $1.16 \pm 0.09$ & $0.04 \pm 0.00$ & $2.08 \pm 0.13$ & $16.28 \pm 3.91$ & ND & $11.89 \pm 2.63$ & ND & $0.26 \pm 0.1$ \\
\hline B & $1.78 \pm 0.04$ & ND & $2.67 \pm 0.67$ & $0.01 \pm 0.00$ & $1.21 \pm 0.08$ & $0.01 \pm 0.00$ & $2.78 \pm 0.23$ & $12.71 \pm 3.19$ & $0.03 \pm 0.01$ & $4.73 \pm 0.82$ & ND & $0.09 \pm 0.01$ \\
\hline E & $2.86 \pm 0.18$ & ND & $3.86 \pm 0.31$ & $0.01 \pm 0.00$ & $1.31 \pm 0.21$ & $0.01 \pm 0.00$ & $3.21 \pm 0.53$ & $19.23 \pm 4.32$ & $0.02 \pm 0.00$ & $4.328 \pm 1$ & ND & $0.42 \pm 0.11$ \\
\hline $\mathrm{F}$ & $4.26 \pm 0.42$ & ND & $3.46 \pm 0.92$ & $0.01 \pm 0.00$ & $1.2 \pm 0.08$ & ND & $2.29 \pm 0.06$ & $11.56 \pm 2.98$ & $0.01 \pm 0.00$ & $22.35 \pm 4.32$ & ND & $0.38 \pm 0.08$ \\
\hline G & $2.68 \pm 0.28$ & ND & $4.83 \pm 0.82$ & $0.02 \pm 0.00$ & $1.28 \pm 0.11$ & $0.02 \pm 0.00$ & $1.83 \pm 0.03$ & $16.27 \pm 3.07$ & $0.02 \pm 0.00$ & $5.63 \pm 1.21$ & ND & $0.54 \pm 0.14$ \\
\hline $\mathrm{H}$ & $2.84 \pm 0.31$ & ND & $2.81 \pm 0.81$ & $0.02 \pm 0.00$ & $1.52 \pm 0.2$ & $0.02 \pm 0.00$ & $1.28 \pm 0.08$ & $11.02 \pm 3.11$ & $0.02 \pm 0.00$ & $3.2 \pm 1.23$ & ND & $0.18 \pm 0.00$ \\
\hline $\mathrm{L}$ & $2.32 \pm 0.86$ & ND & $5.35 \pm 1.1$ & $0.01 \pm 0.00$ & $1.08 \pm 0.12$ & $0.03 \pm 0.00$ & $3 \pm 0.11$ & $17.28 \pm 3.29$ & $0.02 \pm 0.00$ & $2.34 \pm 0.84$ & ND & $0.17 \pm 0.06$ \\
\hline M & $2.86 \pm 0.27$ & ND & $3.29 \pm 0.32$ & $0.02 \pm 0.00$ & $1.11 \pm 0.09$ & $0.01 \pm 0.00$ & $5.62 \pm 1.1$ & $18.22 \pm 2.22$ & $0.01 \pm 0.00$ & $4.52 \pm 1.28$ & ND & $0.14 \pm 0.02$ \\
\hline $\mathrm{N}$ & $2.63 \pm 0.82$ & ND & $4.21 \pm 0.62$ & $0.01 \pm 0.00$ & $1.36 \pm 0.1$ & ND & $2.83 \pm 0.00$ & $19.25 \pm 4.72$ & $0.03 \pm 0.00$ & $32.45 \pm 3.28$ & ND & $0.28 \pm 0.03$ \\
\hline 0 & $4 \pm 0.89$ & 0.00 & $4.06 \pm 0.57$ & $0.02 \pm 0.00$ & $1.43 \pm 0.11$ & $0.03 \pm 0.00$ & $2.06 \pm 0.06$ & $15.29 \pm 3.82$ & $0.01 \pm 0.00$ & $5.38 \pm 1.11$ & 0.00 & $0.19 \pm 0.07$ \\
\hline $\mathrm{P}$ & $1.86 \pm 0.13$ & 0.00 & $3.83 \pm 0.24$ & $0.03 \pm 0.00$ & $1.19 \pm 0.06$ & $0.04 \pm 0.00$ & $6.83 \pm 1.08$ & $16.28 \pm 2.99$ & $0.04 \pm 0.00$ & $4.32 \pm 1$ & 0.00 & $0.21 \pm 0.05$ \\
\hline$Q$ & $3.26 \pm 0.37$ & 0.00 & $2.77 \pm 0.18$ & $0.01 \pm 0.00$ & $1.17 \pm 0.07$ & ND & $0.92 \pm 0.07$ & $12.64 \pm 3.29$ & $0.02 \pm 0.00$ & $37 \pm 7.62$ & 0.00 & $0.22 \pm 0.06$ \\
\hline $\mathrm{R}$ & $0.98 \pm 0.08$ & 0.00 & $9.12 \pm 0.97$ & $0.02 \pm 0.00$ & $1.14 \pm 0.06$ & $0.03 \pm 0.00$ & $1.73 \pm 0.08$ & $12.45 \pm 2.86$ & $0.01 \pm 0.00$ & $5.37 \pm 1.22$ & 0.00 & $0.28 \pm 0.08$ \\
\hline S & $3.84 \pm 0.63$ & 0.00 & $2.68 \pm 0.28$ & $0.01 \pm 0.00$ & $1.25 \pm 0.04$ & $0.01 \pm 0.00$ & $2.84 \pm 0.03$ & $18.14 \pm 3.27$ & $0.01 \pm 0.00$ & $19.07 \pm 4.28$ & 0.00 & $0.19 \pm 0.01$ \\
\hline $\mathrm{T}$ & $3.29 \pm 0.94$ & 0.00 & $3.82 \pm 0.38$ & $0.01 \pm 0.00$ & $1.18 \pm 0.09$ & $0.05 \pm 0.00$ & $2.53 \pm 0.12$ & $16.38 \pm 3$ & $0.02 \pm 0.00$ & $8.29 \pm 2.98$ & 0.00 & $0.78 \pm 0.05$ \\
\hline
\end{tabular}

Results are presented as mean \pm standard deviation where $n=5$. Data were statistically compared with WHO/NIS standard at $p<0.05$. ND $=$ Not Detected. 
The result of mineral composition of sachet and bottled water investigated in this study are presented in (Table 4). Calcium is the 5th most abundant element on the earth crust and is very important for human cell physiology [46]. About $95 \%$ of calcium in human body is stored in bones and teeth. High deficiency of calcium in humans may cause rickets, poor blood clotting, bones fracture etc. and the exceeding limit of calcium produced cardiovascular diseases. Calcium plays a key role in bone formation and development [48]. According to WHO [28] standards, its permissible level in drinking water is $50 \mathrm{mg} / \mathrm{L}$. In this study, a range of $0.98-4.86 \mathrm{mg} / \mathrm{L}$ of calcium was observed in sachet water while a range of $0.88-4.42 \mathrm{mg} / \mathrm{L}$ was observed for calcium in bottled water. Calcium present in both sachet and bottled water investigated were below the permissible level by WHO/NIS. This is like the low level of calcium reported for packaged water in Abraka and Warri, Nigeria [49]. Adult within the age bracket of 19-50 years requires $1000 \mathrm{mg} \mathrm{Ca}^{2+}$ [48]. The result of this water analysis signifies that only approximately $0.3 \%$ of calcium dietary reference can be fulfilled when 2 litres of this packaged water are consumed daily. Extensive consumption of these brands of water over some period might be associated with some health issues because of the minute presence of calcium. It is advisable that water with high quantity of calcium within the permissible limit should be consumed always [48]. Although there is no established proof on adverse health effects attributed to excess calcium in drinking water, but excess calcium ions are known to cause water hardness [50].

Chloride is mainly obtained from the dissolution of salts of hydrochloric acid as table salt $(\mathrm{NaCl}), \mathrm{NaCO}_{2}$ and added through industrial waste, sewage, sea water etc. Surface water bodies often have low concentration of chlorides as compare to ground water. It has key importance for metabolic activity in human body and other main physiological processes [22]. High chloride concentration damages metallic pipes and structure, as well as harms growing plants. In this study, chloride ions concentration was observed to vary from $2.85-6.28 \mathrm{mg} / \mathrm{L}$ for bottled water while the chlorine level for sachet water ranged from $1.45-9.12 \mathrm{mg} / \mathrm{L}$. The result is appreciably within the WHO guideline value of maximum permissible concentration of $250 \mathrm{mg} / \mathrm{L}$ desirable for drinking water. This limit has been laid down primarily based on taste considerations.

However, no adverse health effect on humans has been reported from intake of water containing even higher concentrations of chloride [9]. But higher concentration of chloride ions in drinking water can add its taste to the water. The value of chloride observed in this study is like the $1.42-9.00 \mathrm{mg} / \mathrm{L}$ reported for sachet and bottled water marketed in Bauchi metropolis, Nigeria but was higher than $0.31-3.03 \mathrm{mg} / \mathrm{L}$ reported for sachet water analysis in Warri and Abraka, Nigeria [49]. On the other hand, chloride values observed in this study were lower when compared to the range of $5.05-18.97 \mathrm{mg} / \mathrm{L}$ and $8.95-24.80 \mathrm{mg} / \mathrm{L}$ reported for sachet and bottled water respectively in Ghana [50] and 2.94-19mg/L for processed drinking water in Turkey [51].
Copper occurs naturally in water in only minute quantity (few micrograms per liter) in drinking water [33]. The WHO/NIS guideline value for copper in drinking water is set at a maximum of $2 \mathrm{mg} / \mathrm{L}$. In all the sachet and bottled water samples investigated, none of the samples analyzed was observed to contain this trace element higher than the stipulated concentration. While the sachet water was observed to be within $0.87-1.52 \mathrm{mg} / \mathrm{L}$ the bottled water was found to have a copper level that varied from $0.03-0.07 \mathrm{mg} / \mathrm{L}$. One obvious fact with these results is that the sachet water tends to contain more copper than the bottled water. Higher level of copper is not desirable in drinking water as it could cause gastrointestinal disorder [34].

Iron as a trace element was not detected in four (samples $\mathrm{F}$, $\mathrm{K}, \mathrm{N}$ and Q) of the twenty-sachet water representing $20 \%$ while in the remaining $80 \%$, the concentration was observed to vary from $0.01-0.05 \mathrm{mg} / \mathrm{L}$. Among the five bottled water analyzed, three representing $60 \%$ were observed to contain iron at a concentration of $0.01 \mathrm{mg} / \mathrm{L}$ while $40 \%$ of the bottled water produced and/ or sold in Ibadan metropolis does not contain any trace of iron as it was undetected. These observed values are lower than the recommended limit of $0.3 \mathrm{mg} / \mathrm{L}$ stipulated by World Health Organization (WHO) for drinking water. High concentrations of iron can affect the acceptability of drinking water and should be given adequate priority during the processing of drinking water [33].

Potassium is a necessity for the sustenance of a biological system. It is an essential nutrient in intracellular fluid, acid-alkaline balance, osmotic pressure regulation, muscular contraction and nerve impulse conduction [17]. This mineral element was detected in all the packaged water studied. The concentration of potassium varied from $0.87-6.83 \mathrm{mg} / \mathrm{L}$ and $0.75-3.62 \mathrm{mg} / \mathrm{L}$ for sachet and bottled water respectively. The observed value in this present study is satisfactorily within the guideline value by WHO/NIS. Potassium is silver white alkali which is highly reactive with water. Potassium is necessary for living organism functioning hence found in all human and animal tissues particularly in plants cells. The total potassium amount in human body lies between 110 and 140g. It is vital for human body functions like heart protection, regulation of blood pressure, protein dissolution, muscle contraction, nerve stimulus etc. Potassium deficiency is rare but may lead to depression, muscle weakness, heart rhythm disorder etc. [22].

Magnesium is the 8th most abundant element on earth crust and natural constituent of water. It is essential for proper functioning of living organisms and found in minerals like dolomite, magnetite etc. Human body contains about $25 \mathrm{~g}$ of magnesium $(60 \%$ in bones and $40 \%$ in muscles and tissues). According to WHO/NIS standards, the permissible level of magnesium in water should be $50 \mathrm{mg} / \mathrm{L}$. In this present study, magnesium in sachet water ranged from 11.02$22.84 \mathrm{mg} / \mathrm{L}$ while that of bottled water ranged from $9.64-15.76 \mathrm{mg} /$ L. Magnesium present in both sachet and bottled water analyzed were below the permissible level by WHO/NIS.

Manganese is present in water. In this study, two (sample A and I) out of the twenty-sachet water analyzed representing $10 \%$ 
gave no result for manganese. This could be that they contained no manganese or that it was present in the samples in residual amount that could not be detected by the reagent $[10,11]$. Other sachet water analyzed contain between 0.01 and $0.08 \mathrm{mg} / \mathrm{L}$ of manganese while the bottled water had between 0.01 and $0.05 \mathrm{mg} / \mathrm{L}$ of manganese. These values were below the guideline value of $0.50 \mathrm{mg} / \mathrm{L}$ set by WHO/NIS. Large quantity of manganese influences taste in water and encourage the growth of bacteria; though not hazardous but are very unpleasant. Large doses of manganese have also been reported to cause lethargy, irritability, headache, sleeplessness, and leg weakness. This might lead to development of psychological symptoms such as aggressiveness, unaccountable laughter, impulsive acts and absent-mindedness. These in the long run usually result into a Parkinson-like disease [33].

The WHO/NIS guidelines value stipulates a maximum concentration level of sodium in drinking water to be $200 \mathrm{mg} / \mathrm{L}$. The Sodium concentration level in both sachet and bottled water produced and/or sold in Ibadan metropolis analyzed in this study was within this set guideline value. Analysis of the results showed that the sodium concentration of sachet water ranged between $2.34-37.00 \mathrm{mg} / \mathrm{L}$ in this present study while the bottled water brands varied from $3.26-10.10 \mathrm{mg} / \mathrm{L}$. The value observed in this study is low when compared to $7.79-51.43 \mathrm{mg} / \mathrm{L}$ and $11.55-$ $51.43 \mathrm{mg} / \mathrm{L}$ reported for sachet and bottled water in Bolgatanga municipality, Ghana [50]. Sodium has the tendency of affecting the taste of water meant for consumption when its concentrations are above the threshold limit value [50].

Zinc is another example of trace element present in water. The results of this study showed that all the sachet and bottled water samples investigated were observed to contain appreciable quantity of this trace element. The sachet water was observed to have a zinc concentration that ranged from $0.06-0.78 \mathrm{mg} / \mathrm{L}$ while the bottled water was observed to vary from $0.26-0.93 \mathrm{mg} / \mathrm{L}$. Analysis of these results clearly depicts that the values obtained were within the permissible level of 3 and $5 \mathrm{mg} / \mathrm{L}$ recommended by WHO/NIS. Higher concentrations of zinc in water are responsible for stringent tastes in water which are essentially not desirable [22].

The presence of heavy metals such as cadmium (Cd) and lead $(\mathrm{Pb})$ were not detected in all the analyzed water samples. The results showed that the level of metals in all the brand of sampled water was within the recommended range set by World Health Organization (WHO) and Nigeria Indutrial Standard (NIS). The implication of this result is that the manufacturers of these brands of sachet and bottled water obtained raw water from chemically good sources. Chromium was however detected to be within the range of $0.01-0.03 \mathrm{mg} / \mathrm{L}$ in both sachet and bottled water. Analysis of this result shows that all the bottled water exhibit $100 \%$ compliance with WHO/NIS guidelines for chromium in quality water.

Results obtained in this study indicated that both sachet and bottled water produced and/or sold in various part of the Ibadan Metropolis are free from microbiological contaminants, as shown in (Table 5). Total coliforms, faecal coliforms and enterococci were not isolated in any of the twenty-five sampled water. The presence of total coliforms in treated drinking water is a measure of its general sanitary quality whereas the indication of faecal contamination is measured by the presence of faecal coliforms [52]. WHO/NIS limit is that none should be detected in drinking water $[33,34]$. This clearly indicated that both sachet and bottled water produced and/or sold in Ibadan are of good microbiological quality, and thus suitable for human consumption.

Table 5: Bacteriological Qualities of Sachet and Bottled Water Brands produced and/or sold in Ibadan, Nigeria.

\begin{tabular}{|c|c|c|c|}
\hline $\begin{array}{c}\text { Water } \\
\text { Samples }\end{array}$ & $\begin{array}{c}\text { Bacteria } \\
\text { Counts } \\
\text { (CFU/100ml) }\end{array}$ & $\begin{array}{l}\text { Total Coliform } \\
\text { (CFU/100ml) }\end{array}$ & $\begin{array}{c}\text { Faecal } \\
\text { Coliform } \\
\text { (CFU/100ml) }\end{array}$ \\
\hline WHO/NIS & $\mathbf{0}$ & $\mathbf{0}$ & $\mathbf{0}$ \\
\hline \multicolumn{4}{|c|}{ Sachet Water } \\
\hline A & ND & ND & ND \\
\hline B & ND & ND & ND \\
\hline $\mathrm{C}$ & ND & ND & ND \\
\hline D & ND & ND & ND \\
\hline $\mathrm{E}$ & ND & ND & ND \\
\hline $\mathrm{F}$ & ND & ND & ND \\
\hline G & ND & ND & ND \\
\hline $\mathrm{H}$ & ND & ND & ND \\
\hline I & ND & ND & ND \\
\hline $\mathrm{J}$ & ND & ND & ND \\
\hline $\mathrm{K}$ & ND & ND & ND \\
\hline $\mathrm{L}$ & ND & ND & ND \\
\hline M & ND & ND & ND \\
\hline $\mathrm{N}$ & ND & ND & ND \\
\hline 0 & ND & ND & ND \\
\hline $\mathrm{P}$ & ND & ND & ND \\
\hline Q & ND & ND & ND \\
\hline $\mathrm{R}$ & ND & ND & ND \\
\hline$S$ & ND & ND & ND \\
\hline $\mathrm{T}$ & ND & ND & ND \\
\hline \multicolumn{4}{|c|}{ Bottled Water } \\
\hline $\mathrm{U}$ & ND & ND & ND \\
\hline $\mathrm{V}$ & ND & ND & ND \\
\hline $\mathrm{W}$ & ND & ND & ND \\
\hline$X$ & ND & ND & ND \\
\hline Y & ND & ND & ND \\
\hline
\end{tabular}

Number of samples per brand $=5$; ND $=$ not detected (i.e. no gas produced, or no growth detected, i.e. $0.00 \mathrm{CFU} / 100 \mathrm{ml})$.

\section{Conclusion}

The physical, chemical and bacteriological properties as well as mineral composition of the twenty selected sachet water and the five bottled drinking water brands sold and/or produced in Ibadan metropolis were analyzed successfully. Though, the average temperature values of both the sachet and bottled drinking water samples were significantly above the WHO/NIS standard, it did not have any effect on their microbiological quality properties. Total coliforms, faecal coliforms and enterococci bacteria that principally 
characterize drinking water quality were not present in any of the water samples. Generally, the results obtained in this study indicated that sachet and bottled drinking water produced and/ or sold in Ibadan metropolis were of good quality and hygienic for consumption.

\section{Conflict of Interest}

No conflict of interest.

\section{Acknowledgement}

None.

\section{References}

1. Edema MO, Atayese AO, Bankole MO (2011) Pure Water Syndrome: Bacteriological quality of sachet-packed drinking water sold In Nigeria. Afr J Food Agricult Nutr 11(1): 4595-4609.

2. Ogamba AS (2004) Packaged drinking water, how safe? Professionalism IPAN News.

3. Kulshershtha SN (1998) A global outlook for water resources to the year 2005. Water Resourc. Manage. (WRM) 12(3): 167-184.

4. Denloye SA (2004) Quality parameters for packaged water, NAFDAC Laboratory Experience. IPAN News.

5. Omalu ICJ, Eze GC, Olayemi IK, Gbesi S, Adeniran LA, et al. (2011) Contamination of sachet water in Nigeria: Assessment and health impact: online paginated.

6. Ezeugwunne IP, Agbakoba NR, Nnamah NK, Anhalu IC (2009) The Prevalence bacteria in packaged sachet water sold in Nnewi, South East, Nigeria. World J Dairy Food Sci 4(10): 19-21.

7. Mustapha S, Adamu EA (1991) Discussion on Water Problems in Nigeria: Focus on Bauchi State. National Res Inst p: 43-52.

8. Talwar GP, Strivastava LM, Mougil KD (1989) Biochemistry and Human Biology. $2^{\text {nd }}$ (edn.), New York, USA, pp: 237-239.

9. Nelson DL, Cox MM (2005) Lehninger's principle of Biochemistry. Revised Edition p: 21-45.

10. Airaodion AI, Ewa O, Ogbuagu EO, Ogbuagu U, Agunbiade AP, et al. (2019) Evaluation of Potassium Bromate in Bread in Ibadan Metropolis: Fifteen Years after Ban in Nigeria. Asian Food Science Journal 7(4): 1-7.

11. Airaodion AI, Awosanya OO, Ogbuagu EO, Njoku OC, Ogbuagu U, et al. (2019) Assessment of Bread in Ogbomoso Metropolis for the presence of Potassium Bromate. Asian Journal of Research in Biochemistry.

12. Alhassan AJ, Imam AA, Yakasai AM (2008) Quality assessment of sachet water packaged around Kano Metropolis, Nigeria. Bayero J Pure Appl Sci 1(1): 83-87.

13. (2011) WHO Guidelines for Drinking Water Quality. World Health Organization, Geneva, Europe.

14. Obiri Danso K, Okore Hanson A, Jones K (2003) The microbiological quality of drinking water sold on the streets in Kumasi, Ghana. Lett Appl Microbiol 37(4): 334-339.

15. Adediji A, Ajibade LT (2005) Quality of well water In Ede Area, South West Nigeria. J Hum Ecol 17(3): 223-228.

16. Emmanuel O, Oyelude, Solomon A (2011) Quality of sachet water and bottled water in Bolgatanga Municipality of Ghana. Res J Appl Sci Eng Technol 4(9): 1094-1098.

17. Danso Boateng E, Frimpong IK (2013) Quality analysis of plastic sachet and bottled water brands produced or sold in Kumasi, Ghana. International Journal of Development and Sustainability 2(4): 22222232.

18. Uduma MB (2001) Determination of heavy metals in Challawa River. Unpublished Bayero University B.Sc. Project, P: 20-30.
19. Venkatesan KD, Monica Balaji M, Kalavathy V (2014) Microbiological Analysis of Packaged Drinking Water Sold in Chennai. International Journal of Medical Science and Public Health 3(4): 472-476.

20. Yusuf YO, Jimoh AI, Onaolapo EO, Dabo Y (2015) An assessment of sachet water quality in Zaria Area of Kaduna State, Nigeria. Journal of Geography and Regional Planning 8(7): 174-180.

21. Ibrahim MD, Umaru M, Akindele AA (2015) Qualitative Assessment of Sachet and Bottled Water Marketed in Bauchi Metropolis, Nigeria. Chemical and Process Engineering Research 37: 11-23.

22. Meride Y, Ayenew B (2016) Drinking water quality assessment and its effects on resident's health in Wondo genet campus, Ethiopia. Environmental Systems Research 1:1-7.

23. Ojo OOS, Awokola OS (2012) Determination of Groundwater Physiochemical Parameters of shallow Aquifers in Agbowo and Ajibode communities in Oyo State, South Western Nigeria". International Journal of Engineering Research and Development 3(5): 10-23.

24. Oyeku O, Omowumi O, Kupoluyi C (2001) Wholesomeness Studies of Water Produced and Sold in Plastic Sachets (Pure Water) in Lagos Metropolis. Nigerian Food Journal 2(11): 63-69.

25. APHA (2005) Standard Methods for the Examination of Water and Wastewater, $21^{\text {st }}$ (edn.), American Public Health Association, American Water Works Association, Water Environment Federation, Washington DC, USA.

26. Oyelola OT, Babatunde AI (2008) Effect of municipal solid waste on the levels of heavy metals in Olusosun dumpsite soil, Lagos state, Nigeria. International Journal of Pure and Applied Sciences 2(1): 17-21.

27. Olaoluwa OJ, Olubukola OA, Deborah DO, Oluwanike O, Oluwaloyin I, et al. (2010) Incidence of drug resistant bacteria and physicochemical properties of Ero Dam, Nigeria. Report and Opinion 2(12): 78-82.

28. WHO (1993) Guidelines for Drinking Water Quality", Vol. 1, Recommendations: Wold Health Organization, Geneva, WHO Publication, Geneva, Switzerland, Europe.

29. Dada AC (2009) Sachet Water phenomenon in Nigeria: Assessment of the potential health impacts. African Journal of Microbiology Research 3(1): 015-021.

30. Musa U, Aliyu MA, Sadiq MM, Mohammed IA, Manase A, et al. (2014) Quality Assessment of Sachet Water in Minna Metropolis of Niger State, Nigeria, Proceedings of $44^{\text {th }}$ Annual Conference, Exhibition of Nigerian Society of Chemical Engineers (NSChE), Owerri, Imo State, Nigeria.

31. Olaoye OA, Onilude AA (2009) Assessment of microbiological quality of sachet-packaged drinking water in Western Nigeria and its public health significance. Public Health 123(11): 729-734.

32. Nwidu LL, Oveh B, Okoriye T, Vaikosen, NA (2008) Assessment of the water quality and prevalence of water borne diseases in Amassoma, Niger Delta, Nigeria, African Journal of Biotechnology 7: 2993-2997.

33. WHO (2001) Guidelines for Drinking Water Quality: Microbial Methods". ( $2^{\text {nd }}$ edn), Vol. 1, World Health Organization, Geneva, Switzerland, Europe.

34. NIS (2007) Nigerian Industrial Standard for Drinking Water Quality. Standards Organization of Nigeria (SON) pp: 4-9.

35. Prescott LM, Harley JP, Klein DA (1999) The influence of environmental factors on growth. Microbiology, ( $4^{\text {th }}$ edn), Mc Graw-Hill, USA.

36. Onweluzo JC, Akuagbazie CA (2010) Assessment of the Quality of Bottled and Sachet Water Sold In: Nsukka Town, Agro-Science Journal of Tropical Agriculture, Food, Environment and Extension 9(2): 104-110.

37. McKee JE, Wolf HW (1963) Water quality criteria, $2^{\text {nd }}(e d n$.), State Water Quality Control Board, Publ. No. 3-A, Sacramento, CA, USA.

38. Wetzel RG (2001) Limnology: Lake and River Ecosystems $3^{\text {rd }}$ (edn.), San Diego, Academic Press, CA, USA.

39. (2014) Department of Wildlife \& Fisheries Sciences. Plant Identification. In: Aqua Plant: A Pond Manager Diagnostics Tools.

40. Havens K (2013) Sampling in Plankton Web. 
41. NOAA (2014) Harmful Algal Blooms. In: National Ocean Service.

42. Lindsey R, Scott M (2010) What are Phytoplankton? In: NASA Earth Observatory.

43. NOAA (2014) What are Phytoplankton? In: National Ocean Service.

44. Stewart R (2005) Distribution of Plankton. In Oceanography in the $21^{\text {st }}$ Century-An Online Textbook.

45. Asamoah DN, Amorin R (2011) Assessment of the quality of bottled/ sachet water in the Tarkwa-Nsuaem municipality (TM) of Ghana. Res J Appl Sci Eng Technol 3(5): 377-385.

46. Aremu MO (2011) Physicochemical characteristics of stream, well and borehole water sources in Eggon, Nasarawa State, Nigeria. J Chem Soc Nigeria 36(1): 131-136.

47. Edimeh PO, Eneji IS, Oketunde OF, Shaato R (2011) Physico-chemical parameters and some heavy metals content of Rivers Inachalo and Niger in Idah, Kogi State. J Che Soc Nigeria 36(1): 95-101.
48. Guler C, Alpaslan M (2009) Mineral content of 70 bottled water brands sold on the Turkish market: Assessment of their compliance with current regulations, Journal of Food Composition and Analysis 22(7-8): 728-737.

49. Ndinwa CCG, Chukumah OC, Edafe EA, Obarakpor KI, Morka W, et al. (2012) Journal of Environmental Management and Safety 3(2): 145-160.

50. Oyelude EO, Ahenkorah S (2012) Quality of Sachet Water and Bottled Water in Bolgatanga Municipality of Ghana, Research Journal of Applied Sciences, Engineering and Technology 4(9): 1094-1098.

51. Guler C (2007) Evaluation of maximum contaminant levels in Turkish bottled drinking waters utilizing parameters reported on manufacturer's labeling and government-issued production licenses. Journal of Food Composition and Analysis 20(3-4): 262-272.

52. Ashbolt NJ, Grabow WK, Snossi M (2001) "Indicators of microbial water quality". In: Fewtrell L, Bartram J (Edts.), Water Quality Guidelines: Guidelines, Standards and Health, World Health Organisation Water Series, IWA Publishing, London, pp: 289-316. 